\title{
Development of High Performance Intermediate Temperature Proton- conducting Solid Oxide Electrolysis Cells
}

\author{
Wei Wu, Dong Ding, Ting He
}

October 2017

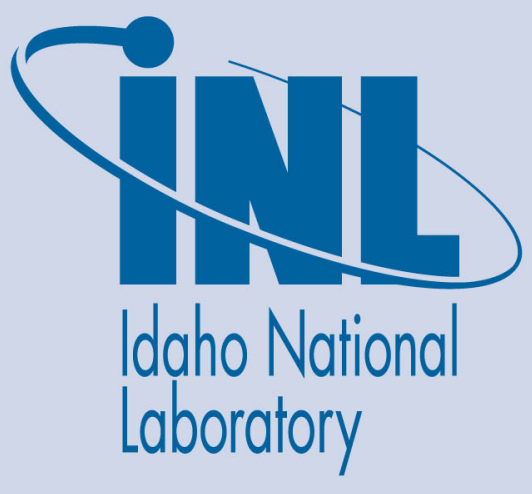

The INL is a U.S. Department of Energy National Laboratory operated by Battelle Energy Alliance 


\section{Development of High Performance Intermediate Temperature Proton-conducting Solid Oxide Electrolysis Cells}

Wei Wu, Dong Ding, Ting He

October 2017

Idaho National Laboratory Idaho Falls, Idaho 83415

http://www.inl.gov

Prepared for the U.S. Department of Energy Office of Nuclear Energy Under DOE Idaho Operations Office Contract Unknown 


\title{
Development of High Performance Intermediate Temperature Proton-conducting Solid Oxide Electrolysis Cells
}

\author{
Wei Wu, Dong Ding, Ting He \\ Idaho National Laboratory, Idaho Falls, ID 83415, USA
}

\begin{abstract}
Steam electrolysis by solid oxide fuel cell technology, known as SOEC, is considered one of the most efficient and cost effective options for hydrogen production from renewable sources. By using proton-conducting electrolyte, the SOEC operating temperature can be reduced from over $800^{\circ} \mathrm{C}$ to below $600^{\circ} \mathrm{C}$ due to higher conductivity and lower activation energy. Technical barriers associated with the conventional oxygen-ion conducting SOECs, such as hydrogen separation from water, oxidation of steam electrode, and instability of oxygen electrode, can be largely mitigated. In this report, an intermediate temperature $\left(500-600^{\circ} \mathrm{C}\right)$ electrolysis technology was developed where a novel protonconductor and a triple-conducting oxide were used as the electrolyte and oxygen electrode, respectively. The electrolysis cell demonstrated excellent performance at intermediate temperatures, promising a new prospective for next-generation steam electrolysis.
\end{abstract}

\section{Introduction}

The growing energy demand and environmental concerns boost the development of renewable and sustainable energies. Hydrogen, one of the most abundant elements in the earth, is regarded as the cleanest fuel that has great potential to replace the carbon-based fuels.(1) Among all the technologies of $\mathrm{H}_{2}$ production, steam electrolysis in solid oxide electrolysis cells (SOECs) has attracted much attention due to its high efficiency and feasibility to be coupled with renewable resources.(2-7) Solid oxide electrolysis cell is the reverse mode of solid oxide fuel cell (SOFC). It produces hydrogen by splitting steam at one electrode while the oxygen is formed at another.(8) Since water electrolysis is increasingly endothermic with temperature, SOECs can benefit from the reduced electricity demand and avoiding the use of noble metals as electrode catalysts with elevated temperatures.(9) Therefore, steam electrolysis through SOEC system is viable to achieve higher overall efficiency.

The typical materials used in SOECs are basically similar to those used for SOFCs. The most common electrolyte materials for SOEC are ion-conducting materials, such as Yttria Stabilized Zirconia (9-11) and $\mathrm{Sc}_{2} \mathrm{O}_{3}$ stabilized zirconia (12). However, those SOECs based on conventional oxygen-ion conductors have to be operated at high temperatures (typically $800-1000^{\circ} \mathrm{C}$ ) due to the limited ionic conductivity of the electrolytes at lower temperatures.(3) Although the thermodynamic advantage of electricity demand reduce for steam electrolysis, running SOECs at high temperatures has obvious drawbacks, partially as the same as occurring in SOFC at high temperatures.(13) Besides, the more aggressive operation condition resulted in more serious problems, including poor long-term stability(14), interlayer diffusion(15), and other materials problems. (16) To address these issues, the development of electrolysis cells for intermediate temperatures has gained much attention.(17-19) 
Proton conducting oxides, which presents many advantages over oxygen-ion conductors at intermediate temperatures, are subsequently proposed as electrolyte materials for solid oxide cells.(20-22) The proton conducting materials demonstrate much higher ionic conductivity compared with that of oxygen-ion conducting materials in the intermediate temperature range, $(23,24)$ as well as better chemical stability with nickel that is the most commonly used anode/hydrogen electrode catalyst for both SOFCs and SOECs.(25-27) A series of $\mathrm{ABO}_{3}$ perovskite proton-conducting oxides have been proposed as electrolyte materials in electrolysis cells, such as doped $\mathrm{BaCeO}_{3}(28,29), \mathrm{SrCeO}_{3}(30,31)$ and $\mathrm{BaZrO}_{3}(32,33)$. Among which, Y-doped $\mathrm{BaZrO}_{3}$ seems the only proton-conducting electrolyte material that combines both large bulk conductivity and good chemical stability.(23) Therefore, modification of BZY materials has attracted much interest in recent years.(34-36) For example, Zuo et al. reported BZCY has much higher conductivity than BZY while maintaining good chemical stability at $\mathrm{CO}_{2}$ and $\mathrm{H}_{2} \mathrm{O}$ containing atmosphere. Further, Yang et al., found $\mathrm{BaZ}_{\mathrm{r} 0.1} \mathrm{Ce}_{0.7} \mathrm{Y}_{0.2-\mathrm{x}} \mathrm{Yb}_{\mathrm{x}} \mathrm{O}_{3-\delta}(\mathrm{BZCYYb})$, which exhibits the highest ionic conductivity and hydrogen permeability at $500^{\circ}$ to $700^{\circ} \mathrm{C}$. $(37$, 38) Although the development of stable electrolyte proton-conducting SOECs has made big progresses in the past years, the design of the oxygen electrode materials with good electrochemical performance still remains a great challenge, especially at low temperatures. An ideal oxygen electrode material has to simultaneously possess good electronic conductivity and high proton conductivity, as well as good chemical stability towards $\mathrm{H}_{2} \mathrm{O}$. (3) In 2013, Choi et al., reported a double-perovskite cathode material, $\mathrm{PrBa}_{0.5} \mathrm{Sr}_{0.5} \mathrm{Co}_{2-\mathrm{x}} \mathrm{Fe}_{\mathrm{x}} \mathrm{O}_{5+\delta}$ (PBSCF), which has created pore channels that dramatically enhance oxygen ion diffusion and surface oxygen exchange while maintaining excellent compatibility and stability under operating conditions. Test cells based on these cathode materials demonstrated peak power density $2.2 \mathrm{Wcm}^{-2}$ at $600^{\circ} \mathrm{C}$.(39) In the subsequent work, the materials from the same family have been demonstrated to be excellent tripleconducting $\left(\mathrm{H}^{+} / \mathrm{O}^{2-} / \mathrm{e}^{-}\right)$oxides, which have good potentials as oxygen electrode for proton conducting electrolyte.(40)

In this study, we assembled an electrolysis cell with highly conductive BZCYYb electrolyte, PBSCF oxygen electrode and NiO-BZCYYb hydrogen electrode in the cell configuration and demonstrated excellent steam electrolysis performances at temperatures below $600^{\circ} \mathrm{C}$. The electrochemical tests were performed in $\mathrm{H}_{2}$ as the hydrogen electrode purge gas and $3 \% \mathrm{H}_{2} \mathrm{O}-97 \% \mathrm{O}_{2}$ as the oxygen electrode inlet gas.

\section{Experimental}

\section{Electrolyte and Electrode Powder Preparation}

$\mathrm{BaZ}_{\mathrm{r} 0.1} \mathrm{Ce}_{0.7} \mathrm{Y}_{0.2-\mathrm{x}} \mathrm{Yb}_{\mathrm{x}} \mathrm{O}_{3-\delta}$ powder was prepared by the conventional solid state reaction (SSR) method. Stoichiometric amounts of high-purity $\mathrm{BaCO}_{3}, \mathrm{ZrO}_{2}, \mathrm{CeO}_{2}, \mathrm{Y}_{2} \mathrm{O}_{3}$ and $\mathrm{Yb}_{2} \mathrm{O}_{3}$ powders were mixed by ball-milling with stabilized zirconia media in ethanol for $24 \mathrm{~h}$. The resultant mixture was then dried, crushed, and calcined at $1100{ }^{\circ} \mathrm{C}$ for $10 \mathrm{~h}$. The process was repeated until pure perovskite phase was obtained. $\operatorname{PrBa}_{0.5} \mathrm{Sr}_{0.5} \mathrm{Co}_{2-\mathrm{x}} \mathrm{Fe}_{\mathrm{x}} \mathrm{O}_{5+\delta}$ powders were synthesized using a glycine-nitrate process (GNP). Stoichiometric amounts of $\operatorname{Pr}\left(\mathrm{NO}_{3}\right)_{3} \cdot 6 \mathrm{H}_{2} \mathrm{O}$ (Aldrich, 99.9\%, metal basis), $\mathrm{Ba}\left(\mathrm{NO}_{3}\right)_{2}$ (Aldrich, 99\%), $\mathrm{Sr}\left(\mathrm{NO}_{3}\right)_{2}$ (Aldrich, 99\%), $\mathrm{Co}\left(\mathrm{NO}_{3}\right)_{2} \cdot 6 \mathrm{H}_{2} \mathrm{O}$ (Aldrich, 98\%), and $\mathrm{Fe}\left(\mathrm{NO}_{3}\right)_{3} \cdot 6 \mathrm{H}_{2} \mathrm{O}$ (Aldrich, 98\%) were dissolved in distilled water with proper amount of glycine. The solutions were heated up 
to $350^{\circ} \mathrm{C}$ in air and self-ignited to form fine powders, followed by calcination at $600^{\circ} \mathrm{C}$ for 4 hours. The resulting powders were then grinded and calcined again at $900^{\circ} \mathrm{C}$ for another 4 hours to form the final PBSCF powders.

\section{Electrolysis Cell Assembly and Testing}

The fabrication process of SOECs in this work is very similar to that of anode supported SOFCs, which can be seen in our previous reports. $(41,42)$ The prepared SOEC was sealed on an alumina tube using Aremco cerambond 552 sealant, with the air electrode side up. Silver mesh was used as current collectors with attached silver wires as leads. Pure $\mathrm{H}_{2}$ was used during ramping to reduce $\mathrm{NiO}$ fully into metallic $\mathrm{Ni}$, as well as the hydrogen electrode purge gas during steam electrolysis. Pure $\mathrm{O}_{2}$ was introduced into oxygen electrode after going through a bubbler. The steam partial pressure at oxygen electrode side was supposed to be $3 \%$ with a constant $\mathrm{O}_{2}$ flow rate of $100 \mathrm{ml} \mathrm{min}^{-1}$. A schematic illustration of the testing configuration is shown in Figure 1. I-V measurements of both SOFC and SOEC mode were recorded using a Solartron 1400 electrochemical working station.

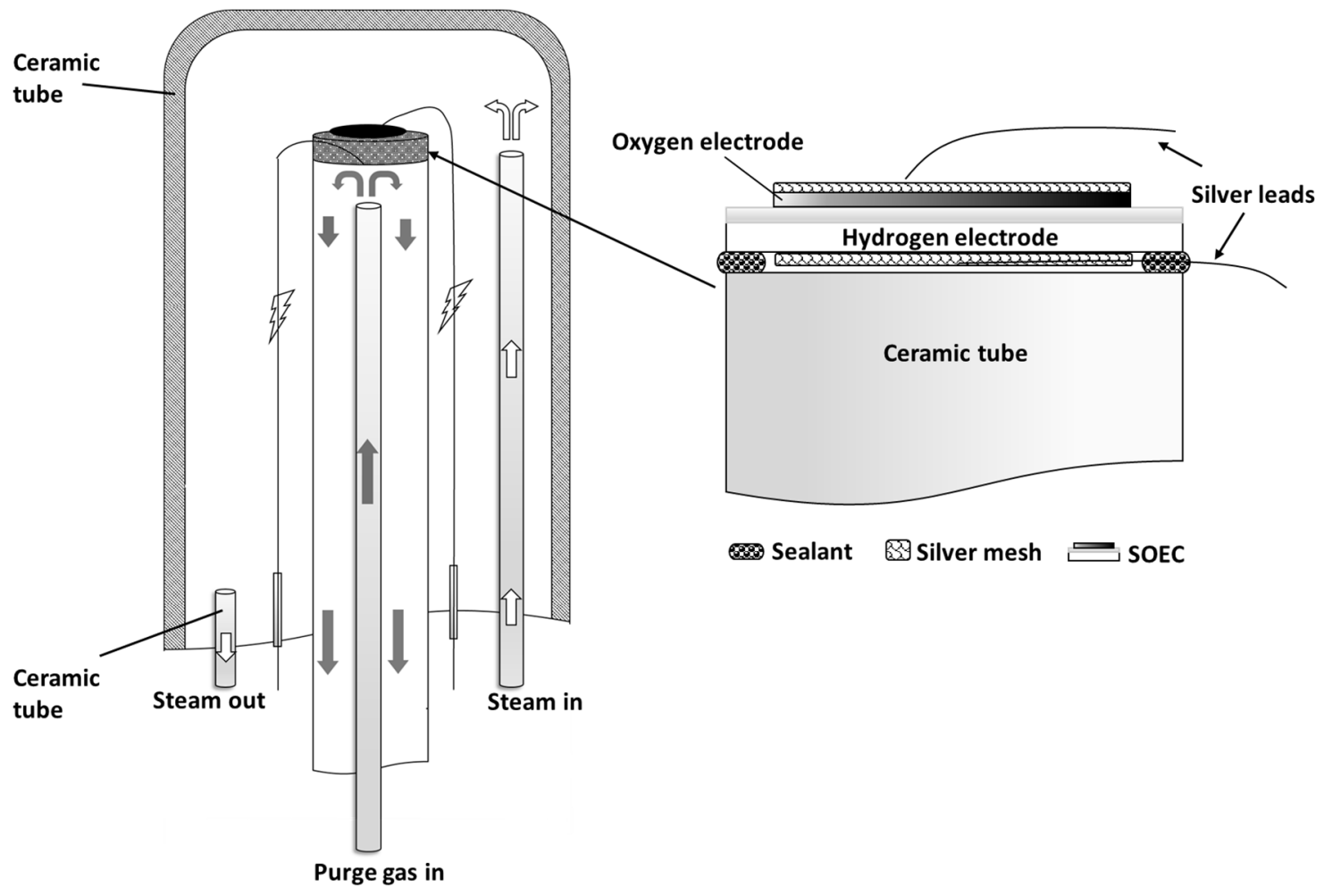

Figure 1. The schematic illustration of SOEC testing set up in this research.

\section{Results and Discussion}

The voltage-current characteristics of the solid oxide cell was investigated in both SOFC and SOEC mode at a temperature range of 500 to $600^{\circ} \mathrm{C}$, as shown in Figure 2, in which the positive current density refers to fuel cell operation while the negative current density refers to electrolysis cell operation. Cell potential values at zero current density correspond to the open circuit voltages (OCV). With $97 \%$ oxygen- $-3 \% \mathrm{H}_{2} \mathrm{O}$ and pure $\mathrm{H}_{2}$ 
introduced into oxygen electrode and hydrogen electrode, respectively, the OCVs of the cell are $1.05,1.07,1.09 \mathrm{~V}$ at 600,550 and $500^{\circ} \mathrm{C}$, respectively. These OCVs are very close to the theoretical values that calculated from Nernst equation, which are $1.13,1.14,1.15 \mathrm{~V}$ at 600,550 and $500^{\circ} \mathrm{C}$, respectively(43), indicating that the electrolyte layer is dense with crossover leakage and the sealing is also good. In SOFC mode (the right part of Figure 2), the slope of I-V curve increases with decrease of operating temperature, which indicates that the ohmic resistance of cell increases. The area specific resistances (ASRs) of the cell in SOFC mode can be calculated from the slope of the $\mathrm{I}-\mathrm{V}$ curves with the section of

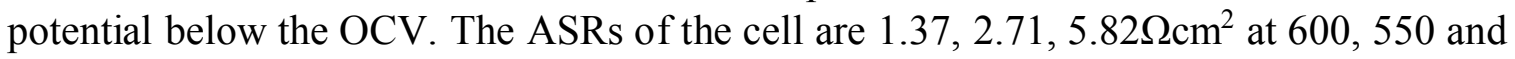
$500^{\circ} \mathrm{C}$, respectively. When the SOFC is discharging at $0.7 \mathrm{~V}$, the current densities are 328 , 136 , and $63 \mathrm{mAcm}^{-2}$ with power densities of 230,95 and $44 \mathrm{mWcm}^{-2}$ at 600,550 and $500^{\circ} \mathrm{C}$, respectively. The performance in SOFC mode was comparable to that of the $\mathrm{BZCYYb}$ fuel cell with $\mathrm{BaCo}_{0.4} \mathrm{Fe}_{0.4} \mathrm{Zr}_{0.2} \mathrm{O}_{3-\delta}$ cathode.(44)

Meanwhile, the change of cell performance in SOEC mode demonstrates the same trend (see the left panel of Figure 2). The ASRs in SOEC mode at 600,550 and $500^{\circ} \mathrm{C}$ are $0.302,0.58,1.14 \Omega \mathrm{cm}^{2}$, respectively, which are significantly lower than that obtained in SOFC mode. This phenomenon was also reported in other works. $(21,45)$ The reason was supposed to be that the absence of water inhibit other charge carrier species rather than protons, and thus improving the proton transference number, which can increase the current efficiency during SOEC applications.(46) When the cell was operated at a potential of 1.5 $\mathrm{V}$, the electrolysis current densities are $-1.33,-0.62,-0.29 \mathrm{~A} \mathrm{~cm}^{-2}$ at 600,550 and $500^{\circ} \mathrm{C}$, respectively. The current density at $500^{\circ} \mathrm{C}$ with applied voltage of $1.5 \mathrm{~V}$ is even comparable with that of SOEC at $700^{\circ} \mathrm{C}$ reported by Bi et al., in 2015.(34)

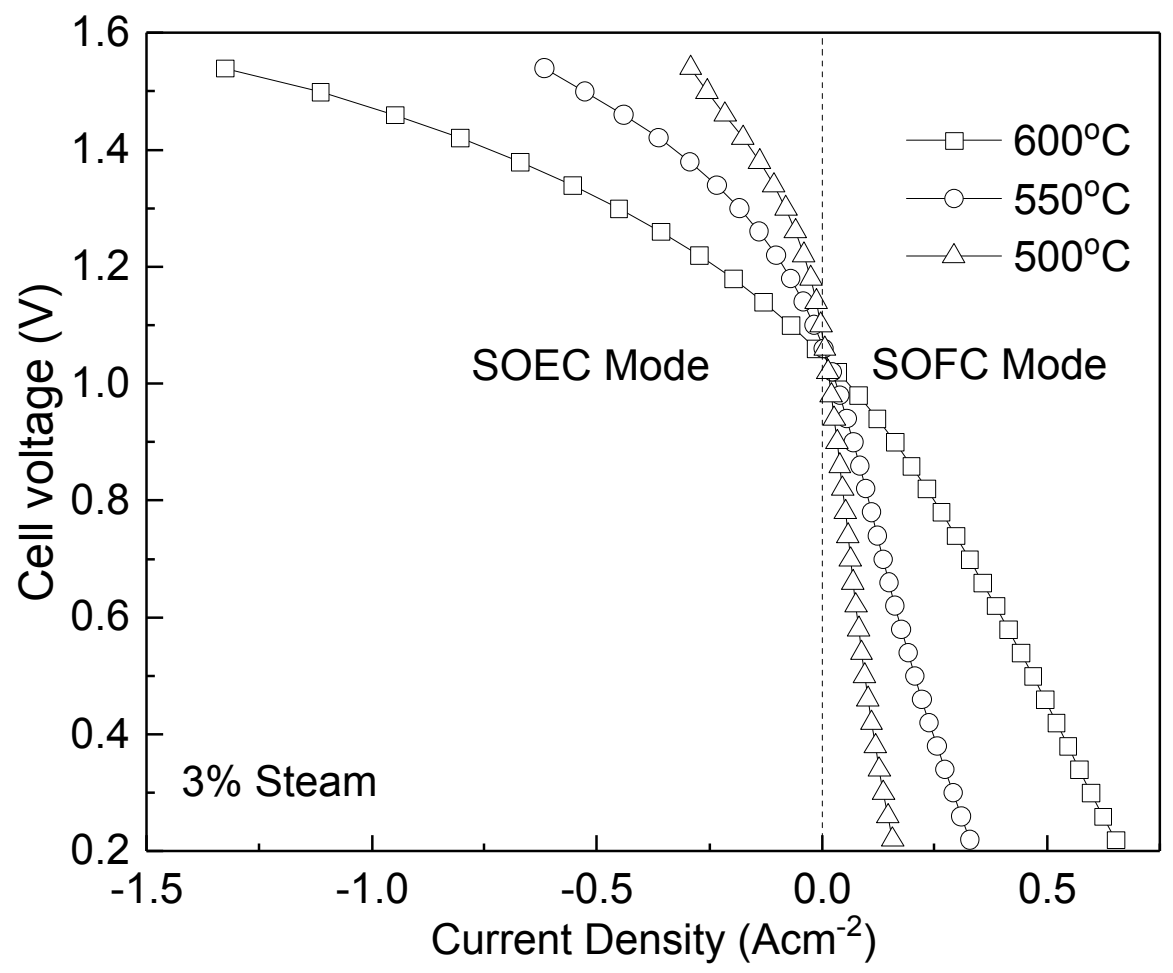

Figure 2. I-V curves of solid oxide cell measured in SOEC and SOFC mode at various temperatures. $\mathrm{H}_{2}$ and $3 \% \mathrm{H}_{2} \mathrm{O}-97 \% \mathrm{O}_{2}$ are used as the reacting gases in hydrogen electrode and oxygen electrode, respectively. 
In this work, pure $\mathrm{O}_{2}$ was introduced into oxygen electrode as carrier gas after going through a bubbler. According to the saturated steam pressure at room temperature, the steam volume ratio was $\sim 3 \%$. Further research will be conducted to investigate the influence of different steam ratios, novel oxygen electrode materials and structures.

\section{Conclusions}

A high performance reversible solid oxide cell has been demonstrated by applying $\mathrm{BaZ}_{\mathrm{r} 0.1} \mathrm{Ce}_{0.7} \mathrm{Y}_{0.2-\mathrm{x}} \mathrm{Yb}_{\mathrm{x}} \mathrm{O}_{3-\delta}$ as electrolyte, $\mathrm{PrBa}_{0.5} \mathrm{Sr}_{0.5} \mathrm{Co}_{2-\mathrm{x}} \mathrm{Fe}_{\mathrm{x}} \mathrm{O}_{5+\delta}$ as oxygen electrode and $\mathrm{NiO}-\mathrm{BaZ}_{\mathrm{r} 0.1} \mathrm{Ce}_{0.7} \mathrm{Y}_{0.2-\mathrm{x}} \mathrm{Yb}_{\mathrm{x}} \mathrm{O}_{3-\delta}$ as hydrogen electrode. The electrochemical performance were tested at temperatures from 500 to $600^{\circ} \mathrm{C}$ in both SOEC and SOFC mode. The OCVs were close to the theoretical values at operating temperatures, indicating a good sealing and no gas leakage across the BZCYYb electrolyte. At $600^{\circ} \mathrm{C}$, the power density (in SOFC mode) is $230 \mathrm{mWcm}^{-2}$ at $0.7 \mathrm{~V}$, while the electrolysis current densities (in SOEC mode) reaches $-1.33 \mathrm{Acm}^{-2}$ at $1.5 \mathrm{~V}$.Our approach suggested a great prospective of developing high performance SOECs at reduced temperature.

\section{Acknowledgements}

The authors gratefully acknowledge the Idaho National Laboratory Directed Research and Development Program under DOE Idaho Operations Office for the support of this work.

\section{Reference}

1. $\quad$ S. Young, Nature, 414, 487 (2001).

2. C. J. Zhang, Y. Yu, M. E. Grass, C. Dejoie, W. C. Ding, K. Gaskell, N. Jabeen, Y. P. Hong, A. Shayorskiy, H. Bluhrn, W. X. Li, G. S. Jackson, Z. Hussain, Z. Liu and B. W. Eichhorn, J. Am. Chem. Soc., 135, 11572 (2013).

3. L. Bi, S. Boulfrad and E. Traversa, Chem Soc Rev, 43, 8255 (2014).

4. M. A. Laguna-Bercero, Journal of Power Sources, 203, 4 (2012).

5. $\quad$ X. Yang and J. T. S. Irvine, J Mater Chem, 18, 2349 (2008).

6. W. Q. Zhang, B. Yu, P. Zhang, J. Chen and J. M. Xu, Progress in Chemistry, 18, 832 (2006).

7. Y. Zheng, T. Chen, Q. Li, W. Wu, H. Miao, C. Xu and W. G. Wang, Fuel Cells, 14, 1066 (2014).

8. G. Tsekouras, D. Neagu and J. T. S. Irvine, Energy Environ Sci, 6, 256 (2013).

9. A. Brisse, J. Schefold and M. Zahid, International Journal of Hydrogen Energy, 33, 5375 (2008).

10. A. Hauch, S. D. Ebbesen, S. H. Jensen and M. Mogensen, J Mater Chem, 18, 2331 (2008).

11. Y. Zheng, Q. Li, W. Guan, C. Xu, W. Wu and W. G. Wang, Ceramics International, 40, 5801 (2014).

12. M. A. Laguna-Bercero, S. J. Skinner and J. A. Kilner, Journal of Power Sources, 192, 126 (2009). 
13. D. Ding, X. X. Li, S. Y. Lai, K. Gerdes and M. L. Liu, Energy \& Environmental Science, 7, 552 (2014).

14. M. Sohal, C. Stoots, V. Sharma, B. Yildiz and A. Virkar, Journal of Fuel Cell Science and Technology, 9, 011017 (2012).

15. P. Moçoteguy and A. Brisse, International journal of hydrogen energy, 38, 15887 (2013).

16. N. Q. Minh, Journal of the American Ceramic Society, 76, 563 (1993).

17. L. Bi, S. Boulfrad and E. Traversa, Solid State Ionics, 275, 101 (2015).

18. A. Ursua, L. M. Gandia and P. Sanchis, Proceedings of the IEEE, 100, 410 (2012).

19. T. Ishihara, N. Jirathiwathanakul and H. Zhong, Energy \& Environmental Science, 3, 665 (2010).

20. H. Iwahara, Y. Asakura, K. Katahira and M. Tanaka, Solid State Ionics, 168, 299 (2004).

21. F. He, D. Song, R. Peng, G. Meng and S. Yang, Journal of Power Sources, 195, 3359

(2010).

22. E. Fabbri, L. Bi, D. Pergolesi and E. Traversa, Adv Mater, 24, 195 (2012).

23. K. D. Kreuer, Annual Review of Materials Research, 33, 333 (2003).

24. B. Zhu, Solid State Ionics, 145, 371 (2001).

25. W. Wu, W. B. Guan, G. L. Wang, F. Wang and W. G. Wang, Adv Energy Mater, 4 (2014).

26. Y. Zheng, J. C. Wang, B. Yu, W. Q. Zhang, J. Chen, J. L. Qiao and J. J. Zhang, Chemical Society Reviews, 46, 1427 (2017).

27. W. P. Pan, K. F. Chen, N. Ai, Z. Lu and S. P. Jiang, J Electrochem Soc, 163, F106

(2016).

28. J. Lyagaeva, N. Danilov, G. Vdovin, J. F. Bu, D. Medvedev, A. Demin and P. Tsiakaras, J Mater Chem A, 4, 15390 (2016).

29. H. Iwahara, H. Uchida and K. Morimoto, J Electrochem Soc, 137, 462 (1990).

30. H. Iwahara, T. Esaka, H. Uchida and N. Maeda, Solid State Ionics, 3, 359 (1981).

31. H. Iwahara, H. Uchida and I. Yamasaki, International journal of hydrogen energy, 12, 73 (1987).

32. S. P. Shafi, L. Bi, S. Boulfrad and E. Traversa, J Electrochem Soc, 162, F1498 (2015).

33. E. Fabbri, A. D'Epifanio, S. Sanna, E. Di Bartolomeo, G. Balestrino, S. Licoccia and E.

Traversa, Energy \& Environmental Science, 3, 618 (2010).

34. L. Bi, S. P. Shafi and E. Traversa, J. Mater. Chem. A, 3, 5815 (2015).

35. G. S. Reddy and R. Bauri, J Alloy Compd, 688, 1039 (2016).

36. W. Zajac, D. Rusinek, K. Zheng and J. Molenda, Cent Eur J Chem, 11, 471 (2013).

37. L. Yang, S. Wang, K. Blinn, M. Liu, Z. Liu, Z. Cheng and M. Liu, Science, 326, 126 (2009).

38. M. F. Liu, W. P. Sun, X. X. Li, S. Peng, D. Ding, D. C. Chen, M. L. Liu and H. C. Park, Int J Hydrogen Energ, 38, 14743 (2013).

39. S. Choi, S. Yoo, J. Kim, S. Park, A. Jun, S. Sengodan, J. Kim, J. Shin, H. Y. Jeong, Y. Choi, G. Kim and M. Liu, Sci Rep, 3, 2426 (2013).

40. J. Kim, S. Sengodan, G. Kwon, D. Ding, J. Shin, M. L. Liu and G. Kim, Chemsuschem, 7, 2811 (2014).

41. W. Wu, W. Guan and W. Wang, Journal of Power Sources, 279, 540 (2015).

42. M. F. Liu, D. Ding, Y. H. Bai, T. He and M. L. Liu, J Electrochem Soc, 159, B661 (2012).

43. Y. Liu, L. Yang, M. Liu, Z. Tang and M. Liu, Journal of Power Sources, 196, 9980 (2011).

44. $\quad$ M. Shang, J. Tong and R. O'Hayre, RSC Advances, 3, 15769 (2013).

45. P. A. Stuart, T. Unno, J. A. Kilner and S. J. Skinner, Solid State Ionics, 179, 1120 (2008).

46. A. Grimaud, J. M. Bassat, F. Mauvy, P. Simon, A. Canizares, B. Rousseau, M. Marrony and J. C. Grenier, Solid State Ionics, 191, 24 (2011). 